\title{
Territorial Rights of Liberal Democratic States: Challenging the Right to Exclude Immigrants ${ }^{1}$
}

\section{Derechos territoriales de los sectores democráticos liber- ales: cuestionando el derecho a excluir a los inmigrantes}

\author{
MELINA DUARTE \\ Department of Philosophy, UiT The Arctic University of Norway, Norway
}

\begin{abstract}
Should liberal democratic states have the right to exclude immigrants from their territories? This article challenges two key arguments in favor of border control: (1) supporting a state's exclusive right to settlement in a determined territory; and (2) defending the exclusive right of membership to citizens and legal residents. It shows that contemporary states do not hold a relevant connection to a particular piece of land that enables them to justify such exclusive right to settlement and that actual state's members can no longer consistently maintain the right to unilateral coercion capable of restricting access to state membership. Finally, it outlines an alternative understanding of a state's territorial rights.
\end{abstract}

\section{KEYWORDS}

BOUNDARY PROBLEM, DEMOCRACY, LIBERAL DEMOCRATIC THEORY, SOVEREIGNTY, TERRITORY

\section{RESUMEN}

¿Deben tener derecho los estados democráticos liberales a excluir a los inmigrantes de su territorio? Este artículo cuestiona dos argumentos centrales a favor del control de las fronteras: (1) el derecho exclusivo del estado al asentamiento en un determinado ter-

1 For valuable comments on a previous version of this paper I am most grateful to $\mathrm{K}$. Fjørtoft, E. Christensen, T. I. Hanstad, A. Vitikainen, A. Mancilla, L. Beckman, K. LippertRasmussen, and A. Frainer, as well as to both editors of this volume. The paper also benefits from inspiring audiences at UiT, Norway; at UFRGS, Brazil; and ULUDAG University, Turkey. E-mail: melina.duarte@uit.no. 
ritorio; y (2) el derecho exclusivo de los ciudadanos y residentes legales a la pertenencia a dicho estado. El artículo muestra que los estados contemporáneos no mantienen una vinculación inexorable a un trozo particular de tierra que les permita justificar el derecho exclusivo de asentamiento y que los habitantes no pueden defender coherentemente su restricción unilateral al acceso a la pertenencia. Para terminar, el artículo desarrolla una visión alternativa de los derechos territoriales estatales.

PALABRAS CLAVE

DEMOCRACIA, FRONTERAS, SOBERANÍA, TEORÍA DEMOCRÁTICA LIBERAL, TERRITORIO

\section{INTRODUCTION}

Should liberal democratic states have the right to exclude immigrants ${ }^{2}$ from their territories? Liberal democratic states are defined as governments preoccupied with enabling individual rights and freedoms, advocating pluralism and tolerance, and places where laws and policies are directly or representatively determined through universal suffrage. In contrast to a people's democracy, liberal democratic forms of government have been spreading rapidly worldwide (Parekh 1992, 161; Bollen 1993, 1207-8), making it an especially relevant object of study. Nowadays, not only are the United States, Canada, Australia and the Western European countries considered liberal democratic states, but also Brazil, Ghana, Cape Verde, the Philippines, and the Czech Republic, among others (Freedom House's Report 2013). Different liberal democratic states will certainly have specific strategies to achieve these common ends. Some states will be supported by a liberal market, others by a conservative or social welfare system (EspingAndersen 2013). These different economic models will indeed have very specific implications when discussing open borders. These implications will be discussed elsewhere. ${ }^{3}$ Here, I am occupied rather with the similarities engendered in all types of politically liberal democratic systems: they are all said to be sovereign states and have territorial rights according to this denomination.

Territorial rights have most prominently been defined as involving at least three elements: the right to jurisdiction; the right to control and use the natural

2 Immigrants are defined here as people living outside their birth country. Legally, these persons are labeled permanent residents, temporary residents, refugees or asylum seekers, and irregular immigrants.

3 See: Duarte, Melina. «Open Borders and Welfare States: Can't They Really Get Along?» Paper presented orally at the International Conference on «Ethics, Democracy and rights: Contemporary Themes in Ethics and Political Philosophy IV» at the University of Córdoba, Spain, and at the PROVIR Closing Conference at the University of Bergen, Norway. 
resources within their territories; ${ }^{4}$ and the right to control the movement of persons and goods across their territories (Ypi 2013, 242-243; Miller 2011, $252-$ 253; Stilz 2011, 573-574; 2009, 186; Simmons 2001, 306). An initial objection to this division could be that these three elements are inseparable from each other, since the right to jurisdiction seems already to imply the right to use and control natural resources as well as the right to control the movement of persons and goods across territories. If they were shown to be truly inseparable from each other, it would be impossible to reject a state's right to exclude immigrants without a substantial restriction of its right to jurisdiction. However, even David Miller, who argues that these rights normally belong together due to the attachment that people develop to a territory over time, believes there are good reasons not to attach the two latter rights to the former. The reasons he gives have to do with the different nature of each element. Whereas the right to jurisdiction is a right exercised over persons within their territories, and whereas the right to use and control the natural resources is a right exercised over things within their territories, the right to control the movement of persons and goods is a right exercised over persons and things, but from outside the states' territories (Miller 2011, 254). This means that while the former two seek justification in the right that a state has to rule everyone and everything physically present in its territory, the justification of the latter demands the undermining of the problems raised by the unilateral coercion over outsiders in order to protect the insiders against external interference. In other words, it conceives the insiders as not only as the prior holders of rights in a defined territory, but also as having exclusive rights. This exclusive right over a particular territory is derived from the remains of a classic and state-centric conception of sovereignty. Contemporary liberal democratic states, however, are no longer sovereign in the same sense and their territorial rights must therefore change accordingly.

In this article, I will argue that the new conception of sovereignty attached to the liberal democratic states does not consist in the domain and exercise of ultimate power over a certain territory, nor does it imply the right to unilateral coercion. Unlike classic sovereign states ${ }^{5}$, liberal democratic states are increas-

4 For an account on a state's right to control and use the natural resources with global implications, see: Mancilla 2014a. In her work, Mancilla proposes that not only the benefits derived from the countries' exploration of resources should be shared globally, but also the costs caused by natural disasters (Mancilla, 2014b).

5 David Held defines classic sovereignty as the regime of a state that «reigns freely in the constitution of political and economic relations» $(2002,1)$. This means that there is no «final and absolute authority above and beyond the (classic) sovereign state» (2002, 3). Held uses the distinction among the three models of sovereignty (classic, liberal international and cosmopoli- 
ingly committed to democracy and human rights and their political authority is monitored by international courts and supranational authorities (e.g. Held 2002, 17). My argument contains three steps that correspond to three sections. The first two steps can be seen as independent from each other in the sense that usually they engage in different debates, but here they are connected by the progressive scrutiny of two meanings commonly attributed to territory: first, territory is understood as a piece of land and second territory is the physical result of civic boundaries. These two meanings link together the fragmented debate on immigration and borders within the framework of liberal democratic theory. Together the first two steps are the main grounds for the negative foundation of my thesis presented in the third step. I am aware that a full account on the matter still requires a stronger positive defense of my thesis on human mobility, which is only briefly outlined here. ${ }^{6}$ However, my goal in this article is much more modest than to prove my argument to be right. Rather, I want to show only why the other alternatives fail and announce my own contribution as an alternative to be further developed and discussed in forthcoming works.

In the first step, I will show that contemporary liberal democratic states do not have a relevant relationship to a particular piece of territory capable of justifying the exclusive right to settlement (Section II). Once it is shown that the ultimate justification for exclusion cannot lie in the exclusive use and control of particular territory, it will be necessary to examine the alternative which says that people living within a state's jurisdiction might instead acquire the right to exclude immigrants based on membership. Authors such as Miller, Michael Walzer and Seyla Benhabib, for example, argue that territorial borders, although not fitting perfectly with civic boundaries, are the physical result of limitations developed by groups unified by cultural affinities over time (e.g Miller 2011; Walzer 2008; Benhabib 2004). Thus, in the second step, I will argue that the legitimacy of liberal democratic states is derived not from societal, but from individual aspirations for self-determination, where individual autonomy is not restricted to members, but extended to all human beings as free and equal agents. This will lead us to reject the standard conception of democracy that requires a (pre)bounded demos (Section III), and to propose an alternative interpretation of the demos (Section IV). Hence, by defeating the two most important pillars of the arguments in favor of the exclusive right to settlement and membership,

$\tan )$ as ideal types or heuristic devices for his inquiry. He is aware that even when one of these models can be said to predominate in a given time, features and elements from other models can also be found $(2002,2)$.

6 Thanks to Prof. L. Beckman for pressing me on this issue. 
I will show that liberal democratic states can no longer exclude immigrants from their territories based on these two grounds.

\section{STATES' TERRITORIAL RIGHTS AND THE INDIVIDUAL RIGHT TO MOBILITY}

Anna Stilz says that «any successful theory on territorial rights will have to explain not just why a state might have a right to some piece of territory somewhere in the world, but more importantly why it has a right to control a particular piece of the territory» (Stilz 2009, 187; emphasis in the original). This means that, according to her, a sound theory of territorial rights will, above all, have to explain the connection between the state and a particular piece of land. Considering this, she argues, for example, theories in support of a state's territorial rights based on the effectiveness-fairness-justness of their institutions such as the so-called general-rights theories are only able to explain the assigned control of an undetermined territory, but not the requisite connection between states and a particular piece of land capable of justifying the exercise of jurisdiction and the enforcement of power in this determined place (Stilz 2009, 187).

In her Kantian account of territorial rights, Stilz argues that the connection between a state and a particular piece of land is given through the mediation of individuals while holders of rights of occupancy over a determined piece of land are legitimately represented by the states. From this perspective, a state would only be legitimated to expand the individual rights of occupancy into instituted territorial rights under three conditions: when it is capable of implementing an efficient system of property law which confers public meaning to private property within the claimed territory; when the individuals themselves have a say in determining the system of law; and when the state is not a usurper (Stilz 2011, 574). Meeting these three conditions has the advantage of making a state's territorial claim dependent on the legitimate representation of individuals with rights to residency in a determined territory. This means that the pact can be broken once a state loses the support of individuals, since the consent to act in the name of the people is conceived through the state's ability to represent the people's interests. At this point, the justification of a state's territorial rights relies on the requisite assumption that, prior to states, individuals acquire rights of occupancy over a determined territory. Taking this into account, Stilz will have then to define the conditions under which individuals themselves acquire these rights. She mentions that individuals have a right of occupancy: when they reside, or have previously resided, in a determined territory; when their legal residency is fundamental to 
the development of their conception of a good life; and when their residency is not imposed by them on others (Stilz 2011, 585). The addition of this third clause, although shown to be necessary, is to Miller not sufficient to protect peoples from invasion and from the injustice of expulsion. In this case, for example, the descendants of invaders, having remained in the conquered territory, would thus acquire the rights of occupancy there. This is despite the fact that they might be better represented by another state that would also have a claim for territorial rights there (Miller 2011, 256). However, if Miller were right in his objection, and we might have a better concern for the descendants of invaders, a country like Brazil would now perhaps be almost empty.

My concern with Stilz's specification of occupancy rights is different. Although it is meant to protect peoples from invasion, it has the disadvantage of excessively restricting the right of occupancy to residents, discouraging first-entry immigrants and undermining the individual right to mobility. This is essentially because the rights of occupancy are restricted to residents, when, in a non-originary position, to be a resident means to somehow be allowed to move in and settle. Certainly, it follows from Stilz's criteria that any legal resident can acquire rights of occupancy, but once the states take over and start to represent the actual residents, the state expands the individual rights of occupancy into territorial rights conditioning residency to the will of a state and its actual members. Based on that, I think Stilz's list lacks one criterion that accounts for first-entry immigration and mobility. We have to keep in mind that nowadays individuals move. They cross borders more often than ever before, and it is likely that human mobility will increase even more in the near future (IMI Policy 2011). It therefore seems to be rather retrograde to advocate that a state's territorial rights consist in the legitimate representation of their legal residents, if the residents are often moving across borders (Beckman 2012, 18). A better candidate for this mediation would then be the institutions of the state, since its relative stability, led by its residents (in the sense of persons currently occupying/living in a determined territory; Beckman 2012, 21-23) would better serve the purpose of founding a state's jurisdictional rights.

Regarding Stilz's general argument on territorial rights, Miller criticizes her position for being essentially present-oriented, undermining the relevance of history in the definition of a state's territorial rights $(2011,256)$. I criticize Stilz for the same reason, but for a very different purpose. I show that states do not have a restrictive connection to a particular piece of land, but, unlike Miller's nationalistic position, I argue that this lack of a significant relationship will make states incapable of justifying the exclusion of immigrants from their territories based on their alleged exclusive right to settlement or membership. 
Like Miller, I argue that history plays a definitive role in the definition of the existing territorial states. Indeed, the actual border configuration is shaped by historical contingencies such as wars, asymmetrical power relationships, contracts, luck and hazard, and many other types of accidents. However, instead of undermining these contingencies, as Stilz does, I want to show that, because history does matter, a meaningful philosophical account of territorial rights should essentially consider the present border for what it is: the result of mere historical accidents. In this sense, as it would be unseemly to let these contingencies aside, it would also be unseemly to logically grant a kind of necessity to the actual border configuration through historic outcomes. Given that, we see that the connection between a state and a particular piece of land should be viewed as nothing more than a contingency. Of course, these contingencies do not deny the attachment developed over time between individuals and a piece of land, the topic of the following section, but, rather, what is challenged here is that this attachment, when represented by states, generates the exclusive right to settlement. Stilz presupposes this relevance in her statement. This presupposition is certainly useful for making sense of the territorial states we have today, but it is not useful for supporting a theory of territorial rights in a strict sense as she believes.

Stilz's argument is constructed in a way that seems to be valid, because the conclusion is immediately empirically evident, i.e. the actual border. However, the argument cannot be immediately valid because the premise that affirms that a state has a special relationship with a piece of land is falsifiable. To illustrate this potentiality, we can think of the situation where, according to a certain conspiracy theory, the Norwegian government is building a powerful weapon capable of creating earthquakes in different parts of the world by pointing to the evidence of the gigantic towers in Ramfjord. The existence of the towers can indeed be verified visually, but since the towers could be there for any other reason, it does not immediately prove the conspiracy. The same can be said about state borders. The fact that their existence can be verified does not prove that states do have any relevant and exclusive connection to a particular piece of land. We have to remember that, under different conditions, historical outcomes gave us different realities where the ultimate power was not centralized in states, but in cities, provinces, villages, or empires (Sassen 2006).

At this point, we have stated that the current relationship between a state and a particular piece of land is not absolute, but rather the result of a series of contingencies. As such, the connection between the two cannot simply be taken for granted when attempting to ground a successful theory of territorial rights. Now, we have to investigate whether this series of contingencies is a 
sufficient condition to make the connection between a state and a particular piece of land relevant enough to ground a successful theory of territorial rights that conceives the exclusive right to settlement. To do this, for methodological limitations, I will not analyze the merit of states through the historical facts that would probably show each case supporting a different conclusion. On top of this problem, this methodology also has the limitation of not knowing how far back in history we need to go to support an original claim to land and how the past would support a valid claim today.

Rather, my argument consists in showing that the contingencies that are relevant to our times, in the context of the emergence of contemporary liberal democratic states, are no longer capable of justifying the exclusive right to settlement to state members. This is because we have now established a new set of values, which are no longer consistent with the functioning of old institutions in classic sovereign states. The argument against slavery is a good analogy. Slavery was once accepted because it was believed that persons with a certain phenotype were inferior to others. Once equality of value among different phenotypes was established, the argument could no longer be supported. I am not suggesting that slavery or strong border control could be justified in the time period. From a current standpoint, I cannot pretend the agents at the time had the same information that I do, and so I cannot judge them. Thus, my argument does not involve any assessment of right or wrong today, or in the past. I am also not claiming «necessity» based on the approach of eternal truths such as justice. It involves something much more fundamental: an assessment of consistency between what we believe at the moment of the action and how we propose ourselves to act. I am aware that this argument on consistency is vulnerable in the sense that when faced with the choice of either revising values or opening the borders, one could choose the former. However, I do not think that revising our embedded values is an easy task and its revision is, in this sense, not less «idealized» than open borders. ${ }^{7}$ Thus, when we recall the contemporary definition of liberal democratic states stated in the beginning of this article, to me it is the same as saying that these states are committed to the values that compose the essential elements of their definition. From a different perspective such as, for example, a people's democracy, these commitments are indeed contestable, and I do not want to argue that any contemporary state should defend the same values. ${ }^{8}$ However, independent of this, liberal democracy is a relatively recent phenomenon that has been spreading rapidly in op-

7 Thanks to K. Lippert-Rasmussen for questioning me on this issue.

8 Thanks to A. Vitikainen for drawing my attention to this point. 
position to peoples' democracies (Pareck 1992,161; Bollen 1993, 1207-1208) and becoming more and more significative. The increasing spread of liberal democracy is a reason to study its particular context, but it is not the only one. The other reason relates to the particular meaning of sovereignty in use today by liberal democratic states.

Biersteker affirms that different forms of states do engage different meanings of sovereignty and are associated with different conceptions of territoriality over time and place $(2002,158)$. Thus, even if in the general perspective of international law, states are recognized as sovereign irrespective of the values they stand for, and, in this specific sense, liberal democratic states are as sovereign as totalitarian states such as North Korea and Saudi Arabia, there is an extreme difference between the ways these two types of states conceive sovereignty. Not only domestically, but also internationally especially in relation to other similar states. While in liberal democratic states there is a tacit agreement to mutually interfere in each other's domestic affairs, for example in the European Union (EU), in the totalitarian states, sovereignty still means non-interference. Thus, when not generalized, we see that the concepts of sovereignty do change according to the values defended in different types of states. This implies that we cannot pretend to capture one meaning of sovereignty that will be valid for all types of states all the time. Therefore, I am using here a definition of sovereignty that is proper to liberal democratic states and that does not correspond to the general, broad and ambiguous, definition of sovereignty. I believe this liberal democratic conception of sovereignty is still being shaped according to a transnational perspective and I try to advance this definition by contrasting it with what it is not, i.e. the classic conception of sovereignty as defined by Held (2002, 3-5).

In the classic conception of sovereignty, territorial rights were thought to be unavoidably geographic, meaning that a state's jurisdictional rights were exercised over a defined territory. Therefore, preventing free mobility of persons and things across territories was seen as an essential component of state sovereignty. However, contemporary liberal democratic states are sovereign in a new sense: when their political power is legitimated domestically and among other liberal democratic states according to the enabling of democracy and human rights. This recognition depends on the attestation that a state's political power is exercised in order to promote freedom and equality, pluralism and tolerance, and universal suffrage among its subjects. It no longer depends merely on a territorial conception of state jurisdiction. Rather we see that, today, a state's jurisdiction can surpass its physical borders externally as well as internally. Externally, sovereignty can also be exercised virtually (Agnew 2005) as in the 
case of the currency value attached to the US dollar, the dependence between buyers and sellers in the global market, the spread of culture and technology worldwide, as well as jurisprudence, extraterritorial legal enforcement, and others. Internally, jurisdiction might not always correspond to a state's physical borders. Catalonia, the Basque Country, and Galicia, although in unfinished processes of independency, are examples of autonomous communities coexisting inside Spain's geographical borders. If the situation of these autonomous communities was, however, accessed under the old lens of sovereignty that was based on the exercise of power over a particular piece of land, their mere existence seeking the same status as the main state would be considered violations of the state's territory and, consequently, of its sovereignty. Since they are not claiming regional autonomy under the main jurisdiction of the state, these autonomous communities would have to be eliminated either by dismemberment or by cultivated integration. However, the existence of these communities shows that to argue that a state's jurisdictional rights are necessarily exercised over a determined territory is rather primitive, and it does not correspond to our contemporary reality.

Our recent commitment to pluralism also has implications in the actual conception of sovereignty. This commitment implies that liberal democratic states are expected to accommodate diversity within their conventionally established territories. Therefore, these states are composed of diverse nations, groups, and persons, each one with its own coexisting and overlapping boundaries. The task of the state is not to make uniform these internal differences and to dissolve their internal boundaries while reinforcing the external differences and building stronger external borders, but to manage and balance the plurality that creates these boundaries, ensuring autonomy for persons, and ensuring group self-determination for (minority) groups and communities. In this sense, their sovereignty depends on a state's ability to reduce friction by domestically accommodating these differences. Their ability exercised domestically is subject to international appraisal and when minimal conditions defined by human rights are not achieved, humanitarian interventions can be called.

Thus, because sovereignty can be exercised across and beyond a state's physical borders, the classic conception of state sovereignty connected to an exclusive territory is no longer a reason to prevent persons from moving across and beyond these borders. This shows that our contingencies are no longer enough to ground a theory of territorial rights capable of justifying exclusion. As a state's territorial rights are the result of contingencies, the arising contingencies related to an emerging transnational conception of sovereignty are no longer consistent with territorially sovereign states. 


\section{Democracy AND THE INDIVIDUAL RIGHT TO MEMBERSHIP}

In the previous section, I showed that the ultimate justification for exclusion of immigrants from a state's territories can no longer lie in the assumption that a state has a relevant relationship to a particular piece of land that is capable of granting them the exclusive right to settlement in that area. The actual border configuration is the result of contingencies and conventions that are no longer consistent with the old institution of territorially sovereign states. However, it can still be argued that, even though a state's right to exclude cannot be grounded on a state's exclusive right to a particular territory, it could be grounded on the exclusive right to membership. In this sense, a state's territorial borders are not said to have a value per se, but rather as the physical result of bounds developed by groups unified by affinities over time, although these borders may not fit perfectly with the civic boundaries. Opening the borders would then undermine the right of members to control these boundaries, which would potentially destroy their sense of community and their distinctiveness. This counter-argument has usually been powerful enough to support the disturbing requirement of border control by shifting the discourse from a liberal and territorial standpoint, where an individual right to mobility would likely prevail, to the alleged collateral restriction demanded by democracy and membership.

Particularists, defenders of this view, usually recognize that there are universal commitments extended to non-members (e.g. Walzer 2008, 146-147; Benhabib 2004,211 ) that might even lead us to maintain the idea of open borders in the future, but these universal commitments are presented as secondary compared to the commitments toward and among members. These authors operate within the liberal democratic framework, but they identify a tension between liberalism and democracy that, according to them, cannot be surpassed. Benhabib's solution consists, for example, in remedying this tension through constant demands for more flexible immigration policies based on consistent and transparent application and eligibility procedures (Benhabib 2004, 140). She proposes transforming the existing territorial borders into boundaries, i.e. in non-militarized and porous frontiers. However, as the territorial borders are justified to her by the defense of the right to group self-determination of a bounded demos, the transformation of borders into boundaries would not mean that individuals would be free to move since the groups would still have the right to protect these boundaries. ${ }^{9}$

In this context, it appears that a fulfilled liberal democracy is truly unachievable because the universal commitments of liberalism conflict with the

9 I have discussed this issue in more detail in Duarte 2004. 
particular necessities of democracy. Consequently, although they can agree with a comprehensive liberalism that requires the exercise of individual autonomy irrespective of group membership, self-determination is unilaterally interpreted as a right pre-bounded groups have to self-rule. This means that group self-determination appears prior to individual self-determination, i.e. prior to individual autonomy. I want to challenge this view in this section by highlighting some ways in which the tension between liberalism and democracy can be resolved. The solution will require the expansion of the right to membership beyond citizenship or legal residency.

In «Democratic Theory and Border Coercion», Arash Abizadeh has demonstrated that liberalism and democracy are consistent with each other when democracy is understood as it should be: as popular sovereignty (Abizadeh $2008,38)$. According to him, the demos, i.e. the populace of a democracy, must be unbounded originally because a conception of a bounded demos necessarily leads democratic theory to unacceptable internal and external conceptual contradictions. Internally, political power is only legitimated by the people's will, but the holders of this will are not themselves democratically grouped. Externally, popular sovereignty demands that legitimate power requires that the subjects participate in the shaping of the laws and rules they are supposed to follow, but a bounded demos would give the members the illegitimate coercive power to rule non-members (Abizadeh 2008, 47).$^{10}$ Following the unbounded conception of the demos, a state could exclude immigrants from its territories if, and only if, the immigrants themselves could participate in this decision-making. Abizadeh therefore argues that in order to enable this bilateral decision-making process, cosmopolitan institutions would be required. Since we currently lack these types of institutions on a large-scale, states cannot pretend to justify the exclusion of immigrants.

This argument is supported by the understanding that in liberal democratic theory coercion, i.e. the infringement of one's autonomy, must be minimized and applied only when it can be justified by all persons subjected to it. ${ }^{11}$ As the coercion involved in border control is not only exercised over members, but also subjects immigrants, would-be migrants, and settled members of other states to coercive acts or threats (Abizadeh 2010), the states, as agents of this coercion, owe them all some kind of justification. Thus, if states are to maintain their prerogative to control their borders and rightly exclude immigrants from

10 Like Abizadeh, I am committed to an idea of liberalism that presupposes that the individual has the autonomy to identify, pursue and revise the end result (Abizadeh 2008, 39).

11 The consent is expressed thought the procedural legitimacy of representation. 
their territories, they must be able to properly justify this coercion, while also considering the non-member's voice on the topic. As this justification cannot be made at the moment, owing to the lack of proper institutions, contemporary liberal democratic states should not be authorized to exclude immigrants from their territories. ${ }^{12}$

Abizadeh's argument is brilliant, although not flawless. He is successful when exposing the contradictions of conceiving democracy as consisting in a bounded demos and pointing out the need to think otherwise. He is also successful when showing that coercion must be justified by the consultation/ participation of all its subjects. With this, Abizadeh shows precisely what makes the exclusive right to membership unacceptable: the unilateral aspect involved in the determination of membership. We all can see this injustice being exposed while being entertained by Ypi's example of the park bench (Ypi 2013, 248). She describes how she and her friend supposedly developed a certain attachment to a particular bench in a public park after having used and improved it over a long period. After a while, the bench started to provide them a comfortable familiar view and pleasant memories of their conversations. They changed the color of the bench according to their taste and kept it constantly clean. Her point here is to show that even if the bench means something very special to them, she and her friend are not entitled to prevent other people from sharing it. The example might not seem expressive enough to represent a long-term relationship over generations; however, we can easily see that the outcome in the example does not change if we imagine Ypi's grandmother in her place granting her the exclusive right to use the bench today. What the example ultimately shows is that long-term attachment and improvement of a land occupied by a group unified by affinities is not enough to justify coercion against outsiders in order to prevent their access to this land. Furthermore, unilateral coercion consists in the denial of what precisely constitutes the core idea of democracy: «rule while being ruled».

The problem of Abizadeh's argument arises when the diffuseness of an unbounded or global demos makes the democratic process practically unachievable. The demos, to be unbounded, would mean not only that the participation of non-members should be included in the democratic process, but that the demos would change every time according to the focus of coercion. This

12 This argument is very like Robert Goodin's and Carol Gould's defense to the principle of affected interests (See Godin 2007; Gould 2004). To Ludvig Beckman, the coercion principle, such as the one defended by Abizadeh, is the legal correlate of the affected interests principle (Beckman 2009, 47). 
indicates that, although inclusive, his solution does not take into account that popular sovereignty, as well as state sovereignty, requires exclusive membership and stable boundaries (Rousseau 2001, Bk.II, Ch. VIII-X, 83-91). In a larger sense, its feasibility and accountability require a certain kind of closure (Benhabib 2004, 219).

Given this, Sarah Song argues that the coercion principle fails to take into account that democracy is more than a set of mere procedures. It is also a set of values and principles (Song 2012, 41). Thus, it would not be enough to globally expand the conditions for democratic decision-making. In order to safely ensure democratic values and principles such as equality and solidarity, the particular institution of the state would be needed. According to her, the «state secures substantive conditions of democracy and establishes dear links between representatives and their constituents» (Song 2012, 58). Cosmopolitan institutions are, from this perspective, seen as unable to establish these conditions so successfully when compared to states. Cosmopolitan institutions - understood as a world state and not world government ${ }^{13}$ - have, according to her, at least three problems that make them normatively undesirable: the risk of degeneration of the system; the incapacity of preserving social and cultural pluralism; and the possible lack of effectiveness of global management (Song 2012, 61-62). In this context of opposition, states appear to be the fundamental instrument of democracy. This leads Song to reject the unbounded conception of the demos argued by Abizadeh. Song's criticism is well founded and should certainly be taken into account, but, at the same time, her view leads us back to the same problems ably denounced by Abizadeh. We are then at an impasse and the debate needs to be advanced. The challenge is to come up with a conception of democracy that does not require either a bounded or an unbounded demos.

\section{A NON-PRE-BOUNDED DEMOS}

In my view, the challenge of a bounded or unbounded demos can be overcome by conceiving the demos as being what I call «non-pre-bounded». This means that the demoi would still be composed by defined members with rights to group self-determination, as is argued in the bounded conception of the demos, but simultaneously what defines membership and who can be a member should not depend on the state's decision, but rather on the people's

13 Unlike a world government, the world state would be compatible with differentiated political borders and jurisdictions. See Abizadeh 2008, 49; Song 2012, 60. 
decision as it would be in the unbounded conception of the demos. Analogous to this is the functioning of a train line. The line has a determined trajectory, but the passengers on board are constantly changing. ${ }^{14}$

In Table 1, the many differences among these three conceptions of the demos are systematized. It shows that variations occur according to the composition of the demos, its scope or reach, the membership determination, the border configuration, the type of coercion involved, and also the feasibility under current conditions [see Table 1 in the Appendix].

Under the bounded conception, it can be seen that the demos is, first, essentially formed by citizens and then partially expanded to legal residents. Although, in most countries, legal residents still have very limited participation in the shaping of the laws they are subject to -mainly restricted to the local level ${ }^{15}$ - its scope ranges from radically exclusionary to exclusionary, since outsiders are not entitled to any justification beyond some transparency in membership application procedures. As membership is uniquely conferred by states and by the people they represent, it requires a system of border control where unilateral coercion is accepted. Its feasibility under the current conditions is uncontested because it is based in the functioning of our actual institutions.

In the unbounded view, on the other hand, the demos is composed by members and non-members, and its scope is seen as radically inclusionary. Although inclusion is a desirable outcome, its radical amplitude produces undesirable consequences to democracy to the point of making it impractical. Membership is conferred not by the states, but by cosmopolitan institutions responsible for enabling subjects to participate in and submit to coercion. As opening or closing state borders will depend on the subject's will, unilateral coercion from the state's members becomes unacceptable. Although we do already have some cosmopolitan institutions, its feasibility is said to be compromised because it depends on the establishment of these institutions on a large scale, again producing the undesirable effects of instituting a world state.

Finally, in the «non-pre-bounded» model, the demos is still composed of state members, but these state members are not reduced to citizens or legal residents. They are the cosmopolitan citizens who become members of a particular state through the exercise of their own choice: ${ }^{16}$ the choice either to reiterate

14 I thank A. Mancilla for clarifying my thoughts by providing me this analogy.

15 In most countries, legal residents still cannot vote and be eligible for public office at the national level. See Bauböck 2005.

16 I have developed this notion of cosmopolitan citizenship more fully in Duarte, Melina. (submitted) «Cosmopolitan Citizenship: The Right to be a Non-citizen with Electoral Rights». 
Table 1. Synthesis of the three conceptions of demos: bounded demos, unbounded demos, and non-pre-bounded demos.

\begin{tabular}{|c|c|c|c|}
\hline & Bounded Demos & Unbounded Demos & $\begin{array}{c}\text { Non-pre-bounded } \\
\text { Demos }\end{array}$ \\
\hline $\begin{array}{l}\text { Demos } \\
\text { composition }\end{array}$ & $\begin{array}{l}\text { State members, i.e. } \\
\text { citizens and/or legal } \\
\text { residents. }\end{array}$ & $\begin{array}{l}\text { Members and non- } \\
\text { members - global } \\
\text { demos. }\end{array}$ & $\begin{array}{l}\text { State members, i.e. } \\
\text { cosmopolitan citizens } \\
\text { who choose to be a } \\
\text { member of a particu- } \\
\text { lar state. }\end{array}$ \\
\hline Scope & $\begin{array}{l}\text { Radically exclusio- } \\
\text { nary (restricted to the } \\
\text { citizens) or exclusio- } \\
\text { nary (restricted to the } \\
\text { legal residents). }\end{array}$ & $\begin{array}{l}\text { Radically inclusio- } \\
\text { nary. }\end{array}$ & $\begin{array}{l}\text { Inclusionary (based } \\
\text { on self-inflicted ex- } \\
\text { clusion). }\end{array}$ \\
\hline $\begin{array}{l}\text { Membership } \\
\text { determination }\end{array}$ & $\begin{array}{l}\text { By the states and their } \\
\text { actual members. }\end{array}$ & $\begin{array}{l}\text { By cosmopolitan ins- } \\
\text { titutions. }\end{array}$ & $\begin{array}{l}\text { By cosmopolitan ci- } \\
\text { tizens residing in a } \\
\text { state. }\end{array}$ \\
\hline $\begin{array}{l}\text { Border } \\
\text { configuration }\end{array}$ & $\begin{array}{l}\text { Controlled state bor- } \\
\text { ders. }\end{array}$ & $\begin{array}{l}\text { Open or closed boun- } \\
\text { daries, depending on } \\
\text { the members and non- } \\
\text { members decision. }\end{array}$ & Open state borders. \\
\hline Coercion & $\begin{array}{l}\text { Unilaterally exerci- } \\
\text { sed by the states un- } \\
\text { dermining individual } \\
\text { autonomy. }\end{array}$ & $\begin{array}{l}\text { Justified by all sub- } \\
\text { jects of coercion un- } \\
\text { derlining individual } \\
\text { autonomy. }\end{array}$ & $\begin{array}{l}\text { Self-inflicted by all } \\
\text { subjects of coercion } \\
\text { balancing individual, } \\
\text { group and institutio- } \\
\text { nal autonomy. }\end{array}$ \\
\hline $\begin{array}{l}\text { Feasibility } \\
\text { under current } \\
\text { conditions }\end{array}$ & $\begin{array}{l}\text { Practically feasible } \\
\text { based on using exis- } \\
\text { ting institutions of the } \\
\text { states. }\end{array}$ & $\begin{array}{l}\text { Practically unfeasi- } \\
\text { ble. Depending on } \\
\text { the implementation of } \\
\text { cosmopolitan institu- } \\
\text { tions in large-scale. }\end{array}$ & $\begin{array}{l}\text { Practically feasible } \\
\text { when based on exis- } \\
\text { ting institutions (sta- } \\
\text { tes and cosmopoli- } \\
\text { tan institutions), but } \\
\text { depending on their } \\
\text { unprecedented usa- } \\
\text { ge. }\end{array}$ \\
\hline
\end{tabular}


the choice once made for them, e.g. proud citizens; the choice to revise their own choices in different moments of life, e.g. legal residents; or the choice to change what was once determined for them and to acquire new affiliations that better correspond to their conception of good life, e.g. denial of previous affiliations. The point is that although their affiliation to a determined state depends on their own choices, their inclusion in some state is today shown to be required since the states are the current institutions responsible for distributing and enforcing rights and duties. The scope of the demos is then not radically inclusionary as the one mutably including all subjects of coercion, and not (radically) exclusionary as the one restricted to citizens and legal residents. Its scope is inclusionary in that it is self-exclusionary. In this sense, a member of state A, for example, can decide to become a member of state B. Her action of inclusion in B would self-exclude her from A when dual state membership is not possible. ${ }^{17}$ This will make membership determined not by others, but by the self. Each person can deliberately decide which train to board. The individuals themselves, as cosmopolitan citizens, choose to be members of a particular state and define their own membership status. This aspect was lacking from the former two conceptions of membership: the capacity of enrolling responsibility and accountability from membership. State borders would still exist, and the institutions among them would still differ, so all the concerns against a world state are not applicable. However, the existing state borders would be open for individuals. Furthermore, its feasibility is still disputable because although it is based on existing state and cosmopolitan institutions, the innovative use of these institutions has no precedent. It can be speculated that we would have a more just world with open borders where people are politically equal, but also a much more unjust world where people are drastically socially unequal. The practical implications must still be studied. Nonetheless, from a theoretical standpoint, the feasibility of this model basically depends much more on the good will to accept the advances already made in the liberal democratic theory in order to eliminate the shadow of a classic conception of state sovereignty, thus transforming current states into truly modern states.

17 This matter is always complicated because it involves the discussion of the very delicate issue of dual citizenship that some current states accept and others do not. The success of the example depends, however, on the restriction of dual state membership. This restriction does not imply, of course, that multiple memberships in other levels are not possible. Dual state membership, however, does not seem to bring justice and political equality to native-born and foreigners at the same time. Rather, it gives advantages to foreigners who can simultaneously have benefits in more than one state. Considering this, together with López-Guerra $(2005,288)$, I reject this possibility. 


\section{CONCLUSION}

In this article, I have stated that, according to the new developments of liberal democratic theory, contemporary liberal democratic states should no longer have the right to exclude immigrants from their territories. Although control of movement of persons across borders has been considered an essential element of a state's territorial rights, the revision of the territorial rights of emerging liberal democratic states is urged in light of the new conception of sovereignty, which is neither essentially territorial, nor does it require a bounded demos.

In the first part of the argument, I showed that a state does not have a relevant connection to a particular piece of land capable of justifying an exclusive right to settlement. I argued that the relationship between the states and the particular piece of land they currently occupy is the result of a series of historical contingencies. However, although these past contingencies were enough to produce the actual border configuration, in the face of the new set of values we are committed to, they are no longer enough to justify the exclusive right to these territories. It is true that, until recently, sovereignty meant the dominion over a determined territory, and this territory corresponded to a state's jurisdiction. However, we saw that today sovereignty is also exercised virtually, i.e. irrespective of state borders, and also that jurisdiction is not confined or limited to a territory. This new set of values brought to contemporary liberal democratic states supports the enabling of individual rights and freedoms, of pluralism and tolerance, and of universal suffrage. Therefore, the sovereignty of these states depends on their ability to accommodate diversity within their conventionally established territories. Assuming that the actual border configuration is contingent certainly does not make it disappear. Moreover, diversity depends on the maintenance of these borders. The turning point is that the borders are conventional, not «sacred». They exist to moderate diversity, not to exclude people.

In the second part of my argument, I shifted the focus from the impossibility of justifying a state's exclusive right to settlement to the impossibility of justifying the state members exclusive right to membership. This shift was necessary because many liberal democratic theorists, although accepting that the territorial borders do not have a value per se, argue that states need to keep the right to define the demos in order to protect their civic boundaries. However, Arash Abizadeh exposed how contradictory the concept of democracy is when requiring a bounded demos, and proposed replacing it with the alternative conception consisting of an unbounded demos. From this latter perspective, states could exclude immigrants from their territories if, and only if, the immigrants 
themselves were able to participate in this decision. The unbounded conception of the demos proved, however, to be vulnerable to serious criticisms such as the practical limitation of conceiving a demos not only formed by members and non-members, but also having its constitution changing constantly according to diverse focuses of coercion. The debate was advanced with the proposition of a «non-pre-bounded» demos, i.e. a demos that is still composed of defined members, but where membership is not determined by a state's unilateral decision. Rather, membership is determined based on the individual choice a person has to participate in the life of a particular state. A choice made, in principle, by each person individually.

\section{REFERENCES}

AGNEW, JOHN. 2005: «Territoriality and State Authority in Contemporary World Politics». Annals of the Association of American Geographers, 95: 437-61.

ABIZADEH, ARASH. 2008: «Democratic Theory and Border Coercion: No Right to Unilaterally Control Your Own Borders». Political Theory, 36: $37-65$.

. 2010: «Democratic Legitimacy and State Coercion: A Reply to David Miller». Political Theory, 38: 121-30.

BAUBÖCK, RAINER. 2005: «Expansive Citizenship: Voting Beyond Territory and Membership». Political Science and Politics, 38: 683-7.

BECKMAN, LUDVIG. 2009: The Frontiers of Democracy: The Right to Vote and Its Limits. London: Palgrave MacMillan.

. 2012: «Is Residence Special? Democracy in the Age of Migration and Human Mobility». In Beckman, L. and E. Erman, eds., Territories of Citizenship. Chippenham and Eastbourne: Palgrave MacMillan, 18-39.

BENHABIB, SEYLA. 2004: The Rights of Others: Aliens, Residents, and Citizens. Cambridge: Cambridge University Press.

BIERSTEKER, THOMAS J. 2002: «State, Sovereignty and Territory». In Carlsnaes, Walter, Tomas Risse and Beth A. Simmons, eds., Handbook of International Relations. Los Angeles, London, New Delhi, Singapore, Washington DC: Sage, 157-174.

BOLLEN, KENNTH. 1993: «Liberal Democracy: Validity and Method, Factors in Cross-National Measures». American Journal of Political Science, 37:1207-1230.

DUARTE, MELINA. 2014: «Right to Hospitality, Right to Membership: A 
Critical Review of Kant's and Benhabib's Cosmopolitan Accounts on Immigration and Borders». In Alnes J. H. and M. Toscano, eds., Varieties of Liberalism. Newcastle: Cambridge Scholars Publishing, 204-22.

ESPING-ANDERSEN, G囚STA. 2013:The Three Worlds of Welfare Capitalism. Cambridge: Polity Press.

FREEDOM HOUSE. 2013: Report accessed August 2014 at: http://www. freedomhouse.org/sites/default/files/FIW\%202013\%20Booklet.pdf

GOODIN, Robert. 2007: «Enfranchising All Affected Interests, and Its Alternatives». Philosophy and Public Affairs, 5: 40-68.

GOULD, CAROL. 2004: Globalizing Democracy and Human Rights. Cambridge: Cambridge University Press.

HELD, DAVID. 2002: «Law of States, Law of Peoples: Three Models of Sovereignty». Legal Theory, 8: 1-44.

IMI POLICY. 2011: Global «Megatrends» for Future International Migration. In Briefing 9, September.

JACOBSON, DAVID. 1997: Rights Across Borders: Immigration and the Decline of Citizenship. London: John Hopkins University Press.

LÓPEZ-GUERRA, CLAUDIO. 2005: «Should Expatriates Vote?» Journal of Political Philosophy 13: 216-34.

MANCILLA, ALEJANDRA. 2014a: «The Environmental Turn in Territorial Rights». Critical Review of International Social and Political Philosophy. DOI: $10.1080 / 13698230.2013 .868981$. . 2014b: «The Volcanic Asymmetry or the Question of Permanent Sovereignty over Natural Disasters». Journal of Political Philosophy. DOI: 10.1111/jopp. 12038 .

MILLER, DAVID. 2011: «Territorial Rights: Concept and Justification». Political Studies, 60: 252-68.

PAREKH, BIHKHU. 1991: «The Cultural Particularity of Liberal Democracy». Political Studies, 40: 160-175.

ROUSSEAU, JEAN-JACQUES. 2001: Du Contrat Social. Paris: Flammarion.

SASSEN, SASKIA. 2006: Territory, Authority, Rights: From Medieval to Global Assemblages. Princeton, NJ: Princeton University Press.

SIMMONS, JOHN A. 2001: «On the Territorial Rights of States». Philosophical Issues, 11: 300-26.

SONG, SARAH. 2012: «The Boundary Problem In Democratic Theory: Why the Demos Should Be Bounded by the State». International Theory, 4: 39-68.

. 2009: «Democracy and Noncitizen Voting Rights». Citizenship Studies, 
13: 607-20.

STILZ, ANNA. 2011: «Nations, States, and Territory». Ethics, 121: 572-601. 2009: «Why Do States Have Territorial Rights?». International Theory, 1: $185-213$.

WALZER, MICHAEL. 2008. «The Distribution of Membership». In Pogge, T. and D. Moellendorf, eds., Global Justice: Seminal Essays, Global Responsibilities. St. Paul: Paragon House, 145-77.

YPI, LEA. 2013: «Territorial Rights and Exclusion». Philosophy Compass, 8: 241-53. 
